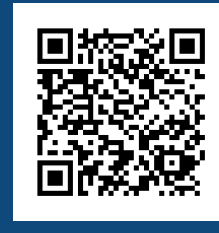

Keywords:

Detached live branches

Girdling

Mate tree

Vegetal reinvigoration

Historic:

Received 23/08/2018

Accepted 16/09/2018

Correspondence: brunonascimento.ef@gmail.com
Bruno Nascimento'+, Alexandra Cristina Schatz Sá', Lucas Bonez de Lemos', Diego Pereira da Rosa', Mariane de Oliveira Pereira', Marcio Carlos Navroski'

\section{THREE EPICORMIC SHOOT TECHNIQUES IN I. paraguariensis MOTHER TREES AND ITS CUTTING ACCORDING TO THE MATERIAL REJUVENATION DEGREE}

NASCIMENTO, B.; SÁ, A. C. S.; LEMOS, L. B.; ROSA, D. P..; PEREIRA, M. O.; NAVROSKI, M. C. Three epicormic shoot techniques in $I$. paraguariensis mother trees and its cutting according to the material rejuvenation degree. CERNE, v. 24, n. 3, p. 240-248, 2018.

\section{HIGHLIGHTS}

Semi-girdling technique produces longer epicormic shoots in native llex paraguariensis.

Cuttings form epicormic shoots produce a higher number of roots than treetop shoots.

Shoots from detached live branches have short length with high number of leaf buds.

New studies are needed regarding techniques to elongate shoots from detached branches.

\section{ABSTRACT}

The induction of epicormic shoots is very important for the success of vegetative propagation in forestry species, due to the high rooting capacity of the reinvigorated material. However, it is necessary to determine the most appropriate technique for this purpose, aiming for greater productivity and better reinvigoration, which may be different for each species. The objective of this search was to evaluate different induction techniques for the production of epicormic shoots in I. paraguariensis mother trees in the municipality of Urupema, Santa Catarina state, considering four rescue techniques: complete girdling (100\%); semi-girdling (50\%); detached live branches, and; shoots of the treetop (canopy). Three evaluations were made for: trees with epicormic shoots (\%), average number of shoots and their average length $(\mathrm{cm})$. Shoots were collected at 180 days after (February 2017) the application of the experiment (August 2016), separating in: rejuvenated shoots and of the treetop. At 90 days, cuttings variables were evaluated: rooting (\%), calogenesis (\%), average root number and their average length $(\mathrm{cm})$. The semi-girdling was superior to shoot length $(5.3 \mathrm{~cm})$. The detached live branches obtained the highest average number of shoots (4.7), however, they were not able for cutting, due to their short length $(0,6 \mathrm{~cm})$. For cutting, there was only difference for the number of roots formed, and the rejuvenated material was superior $(2,3)$ than treetop $(0.8)$. It is recommended the use of semi-girdling technique for greater production of juvenile shoots and use reinvigorated cuttings for vegetative propagation, considering the greater number of roots formed. 


\section{INTRODUCTION}

Ilex paraguariensis Saint Hilaire, also known as mate, is a native species that has a strong cultural and economic link with southern Brazil, since its leaves are used in the production of medicines and consumed largely in the form of teas (Dartora et al., 2013). In 2016, the production of this species grew slightly more than $1.5 \%$ in relation to the previous year. However, the economic value related to the extraction of this raw material decreased by approximately I. $2 \%$ for the same period (IBGE, 2016). This can reflect the depletion of natural resources due to too much extractive activity, the genetic heterogeneity of the extraction areas, poorly implemented management techniques and a high degree of maturation of the mother trees (Medrado et al., 2002; Wendling et al., 2004).

I. paraguariensis trees, which produce raw material for extraction, in a planted or natural way, usually have seminal origin, hampering to establish standards for production management and raw material processing (Wendling, 2004). Its plantations from seminal origin hardly have selection criteria, presenting a high degree of genetic heterogeneity, negatively reflecting the productivity and quality of the final product (Wendling and Brondani, 2015). In addition to the high genetic heterogeneity, there is the natural degradation of its trees due to poor pruning, successive extraction, nutrient depletion, competition for invasive plants and even the aging of the mother trees (Medrado et al., 2002).

These problems can be solved by obtaining seedlings by vegetative propagation, such as the cutting technique, by selecting genetically superior individuals. Plants produced via vegetative propagation tend to have similar productivity of raw material, since they are clones of the same mother tree (Wendling and Brondani, 2015), facilitating the implementation of management techniques (Wendling et al., 2004)

One of the main problems for the success of cutting is strongly related to the ontogenetic age of the plant material, in which the older the material the lower the percentage of rooting of cuttings (Wendling, 2004; Stuepp et al., 2017a, 2017b). Therefore, it is necessary to use techniques that aim to rejuvenate the vegetal material to be used in the vegetative propagation of I. paraguariensis (Wendling and Brondani, 20I5), considering the difficulty of rooting the plant material of lower vigor (Almeida et al., 2007; Brondani et al. 2009, Stuepp et al., 2017a, 2017b).

The dormant buds that are closer to the soil level of the mother tree have high juvenility, since in this place are maintained the seedling characteristics, being able to produce shoots with high vigor, even in high physiologically mature plants (Hartmann et al., 20I I). A reinvigoration technique to promote shooting of dormant buds at the base of the plant is the injury caused by girdling of its trunk (Santin et al., 2008). The removal of the bark of the plant causes a hormonal imbalance between cytokines and auxins, and the accumulation of the first one below the girdle favours the promotion of shoots form dormant buds and its development (Hartmann et al., 20I I).

Alternatively, to produce plant material for vegetative propagation, the technique of detached live branches may be used. This technique consists of the collection of live pruned branches, kept in greenhouse for induction of epicormic shoots (Hartmann et al., 201I). Good results have already been obtained for the promotion of epicormic shoots via detached live branches of Araucaria angustifolia (Bertol) Kuntze (Wendling et al., 2009) and satisfactorily for I. paraguariensis (Wendling et al., 20I3). However, these are also directly related to the ontogenetic age of the mother tree and need to be careful when collecting the material for use in vegetative propagation (Wendling, 2004).

Therefore, the objective of this search was to evaluate the differences in the production of shoots in $I$. paraguariensis trees according to the proportionality of girdling and the use of detached live branches, testing the rooting of cuttings coming from reinvigorated material and from treetop.

\section{MATERIAL AND METHODS}

\section{Characteristics of the area of study}

The field experiment was conducted in an experimental area in the municipality of Urupema, in Santa Catarina. The study area is located approximately I,400 meters above sea level, at the coordinates 28॰17’38' S; 4955'54' W.

This region has a humid temperate climate $(\mathrm{Cfb})$, with annual mean precipitation of $1,650 \mathrm{~mm}$. Being characteristic of the region, during winter can be snow and minimum temperatures of up to $-14^{\circ} \mathrm{C}$, considered the coldest in Brazil (Figure I).

\section{Techniques of epicormic shoot induction}

I. paraguariensis mother trees were dispersed at the experiment site and with average age between 15 and 20 years (according to the owner), with an average diameter of $9.5 \mathrm{~cm}$ (average of 9.8 for plants for complete girdling and 9.2 for semi-girdling), being selected based on their sanitary quality, in August 2016. Also, it is important to report that the mother trees belong to a place of constant harvesting of their 


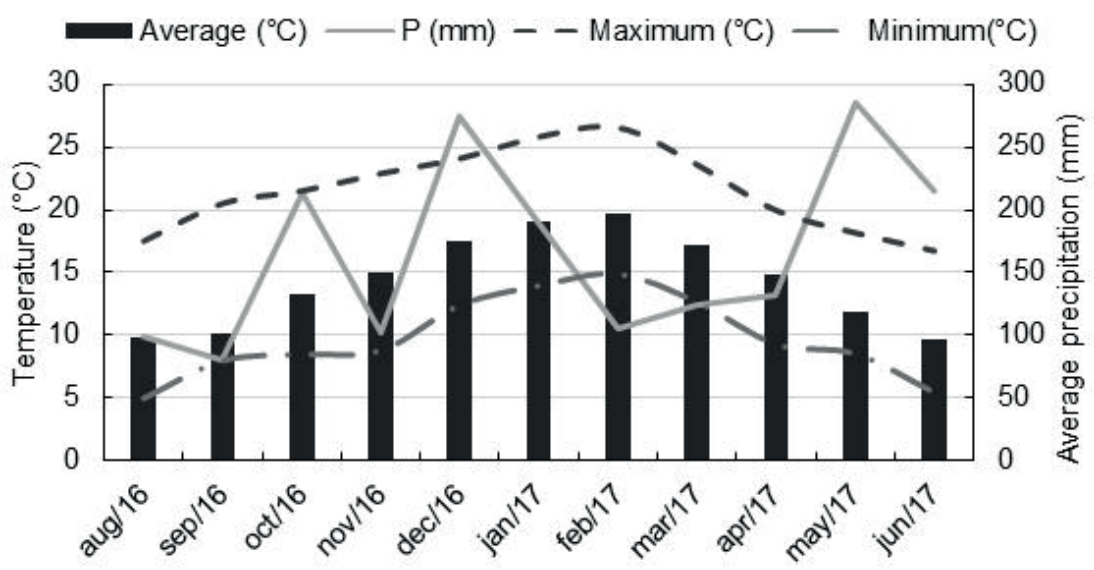

FIGURE I Monthly average of maximum, average, minimum temperatures $\left({ }^{\circ} \mathrm{C}\right)$ and average precipitation $(\mathrm{mm})$ in the municipality of Urupema, Santa Catarina state, for the periods from August 2016 to June 2017. Source: Adapted from Epagri Ciram, 2017.

leaves (raw material), having a smaller total aerial part. The plants were identified in the field with ribbons of different colours for easy visualization according to each rescue treatment applied.

The four techniques of reinvigoration and rescue of vegetal material consisted of: complete girdling (100\%); semi-girdling (50\%); collection of detached live branches; collection of shoots from the treetop (canopy). The treatment of treetop shoots was considered as a control in the rooting of cuttings due to their high availability of material. Therefore, for the statistical evaluation of this experiment, only the first three treatments were considered.

The girdling techniques were applied at a height of $20 \mathrm{~cm}$ from the soil in August 2016. A ring with $5 \mathrm{~cm}$ wide was removed with a machete, only the portion of the outer bark being removed, not affecting the intern wood.

For the treatment of detached live branches, these were obtained from other I. paraguariensis trees to not alter the physiological activity of the mother trees from other treatments. The branches were cut with a chainsaw, eliminating secondary branches and already present shoots. The branches had their ends sealed with plastic and string to avoid excessive moisture loss. Afterwards, they were transported to the Forest Nursery of the State University of Santa Catarina, in Lages, being stored in a mini tunnels system with four daily irrigations by micro aspersion of five minutes each. A live branch was considered the one belonging to a live tree and with presence of leaves, representing being physiologically active.

With 210 days after the application of the techniques (March 2017) began the shooting evaluation of the I. paraguariensis trees previously girdled. The following variables were evaluated: the presence or not of shoots under the ring (\%); average number of shoots formed and; average length of shoots $(\mathrm{cm})$. The same variables were evaluated for live branches in the same period. Also, the selective accuracy (\%) for the significant treatments was verified by the analysis of variance. They were considered trees with shoots if they presented them below the girdle, regardless of their size, as well as to their number. The length was obtained using a common millimetre ruler, measuring from the shoot base (attachment to the trunk) to its apex (insertion of the last leaf).

The experiment was conducted in a completely randomized design with factorial arrangement $3 \times 3$, with factor A consisting of three rescue techniques (consisting of three replicates of three trees each) and $B$ the three evaluations performed every 45 days (March - 210 days, half April - 255 days and June - 300 days).

In parallel, the detached live branches obtained for the rescue were constantly evaluated to determine their shooting speed and lifespan. This experiment was installed at the same moment of conditioning the branches in the Forest Nursery of University of Santa Catarina State (UDESC), in Lages, Santa Catarina state (August 2016) (Figure 2).

Therefore, the diameters of the central region of I 2 branches were determined with a ruler, being properly identified and ordered to facilitate the evaluations. The branches diameters ranged from at least $3.4 \mathrm{~cm}$ to a maximum of $6.1 \mathrm{~cm}$ with lengths close to $70 \mathrm{~cm}$.

The experiment was conducted in a completely randomized design, with six replicates of one branch for each treatment. The treatments were determined in: branches smaller or with a diameter equal to $5 \mathrm{~cm}$, and; branches larger than $5 \mathrm{~cm}$ in diameter. The development of shoots in the branches was evaluated in the form of regression, relating the periods of evaluation and the diameter of branches. Evaluations began 30 days after implantation, occurring every 30 days, with 10 evaluations, from September 2016 to June 2017 (300 days). 


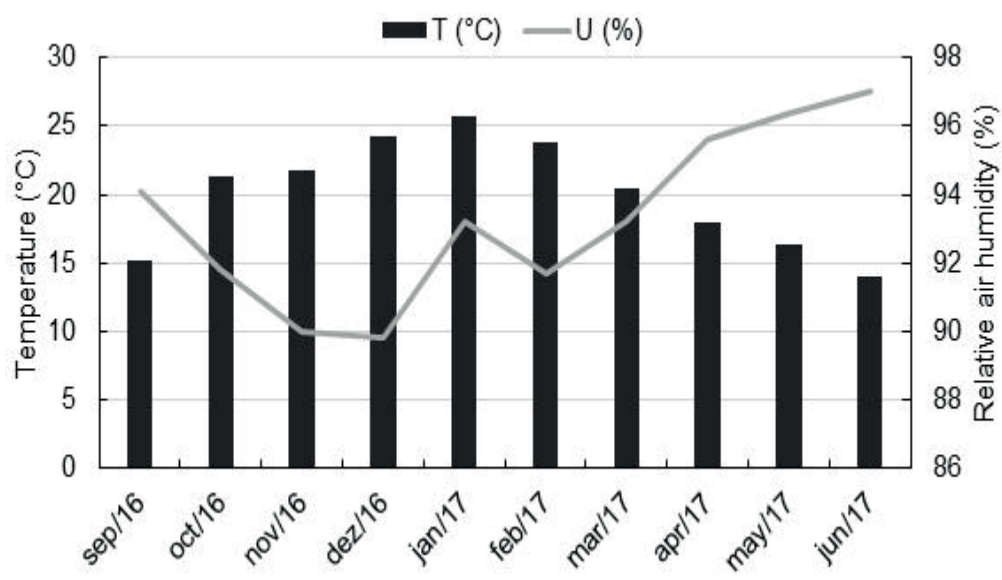

FIGURE 2 Average temperature $\left({ }^{\circ} \mathrm{C}\right)$ and relative air humidity (\%) during the months of $\mathrm{I}$. paraguariensis detached live branch shooting experiment at the UDESC greenhouse in Lages. *Data of August 2016 were not obtained.

Rooting of cuttings obtained from epicormic and treetop shoots

At 150 days (January 2017) the beginning of shooting was detected. Shoots from the induction techniques of epicormic shooting $(>7 \mathrm{~cm})$ and treetop shoots (produced in the year by the tree canopy) were collected in the experimental area 180 days after their application (February 2017). The shoots were inserted in a Styrofoam box with water during transport to avoid excessive moisture loss from the vegetal material, to the Univsersity's Forest Nursery in Lages.

Shoots were sectioned into cuttings with pruning shears, approximately $7 \mathrm{~cm}$ long, with at least one leaf cut in $50 \%$ of their area. Due to the low availability of material, the entire portion of the shoot was used, from the basal (lignified) to the apical (herbaceous) portion. To determine the differences of rooting by cutting, the treatments were: cuttings coming from epicormic shoots, and; cuttings from shoots of the treetop.

The cuttings were set to root in $180 \mathrm{~cm}^{3}$ tubes with a commercial substrate mixture (Maxferti ${ }^{\circledR}$ - mixture of composted Pinus bark and peat, pH between 5.3 and 6.5) and fine vermiculite (Terra Nobre ${ }^{\circledR}$ ) in the proportion $\mathrm{I}: \mathrm{I}$, with addition of $6 \mathrm{~g} \cdot \mathrm{L}^{-1}$ slow release fertilizer (Osmocote ${ }^{\circledR}$, in NPK composition - 15-9-12). The trays, containing the tubes and cuttings, were allocated in the mini tunnels, with micro aspersion irrigation composed of four daily irrigations of five minutes each.

The experiment was conducted in a completely randomized design, with 15 replicates of 10 cuttings for each treatment. At 90 days was evaluated: survival of cuttings (\%); callus formation (\%); rooting (\%); average number of roots, and; average length of the 3 largest roots $(\mathrm{cm})$. Survivors were cuts that had live wood, old leaves or young shoots, rooted or not. For calluses, the cuttings were considered alive, with undifferentiated cell mass at the base, rooted or not. The percentage of rooting was considered on the total, not only on the surviving cuttings. It was considered as rooted those with induction of root primordia of at least $0.2 \mathrm{~cm}$ in length.

A scheme for easy understanding of both experiments is presented in figure below (Figure 3).

\section{Statistical analysis}

We evaluated the normality (Shapiro-Wilk) and homoscedasticity (Bartlett) of the wastefrom both experiments, where, with significance at $5 \%$ probability by analysis of variance (Two-Way ANOVA for the epicormic shoot induction experiment and One-Way ANOVA for the cutting experiment) and with normality Tukey, and without normality, Kruskal-Wallis test, both with a $5 \%$ probability of error, were applied by the statistical program $R$ software.

To evaluate the degree of confidence of the epicormic shoot induction experiment, the calculation of selective accuracy, obtained by the root of one minus one divided by the value of $\mathrm{F}$ obtained from the analysis of variance, provided by Resende and Darte (2007) and Navrsoki et al. (2013), was used. Considering the bands: less than or equal to $50 \%$ (low); between $50 \%$ and $70 \%$ (moderate); between $70 \%$ and 90\% (high); and greater than $90 \%$ (very high).

\section{RESULTS AND DISCUSSION}

\section{Techniques of epicormic shoot induction}

There was no significance for the variable of trees with shoots by variance analysis $(P<0.05)$, and their value was not presented for selective accuracy. For number of shoots formed and mean length of shoots, which were significant, the values were considered very high (92.7\% and $96.4 \%)$. 


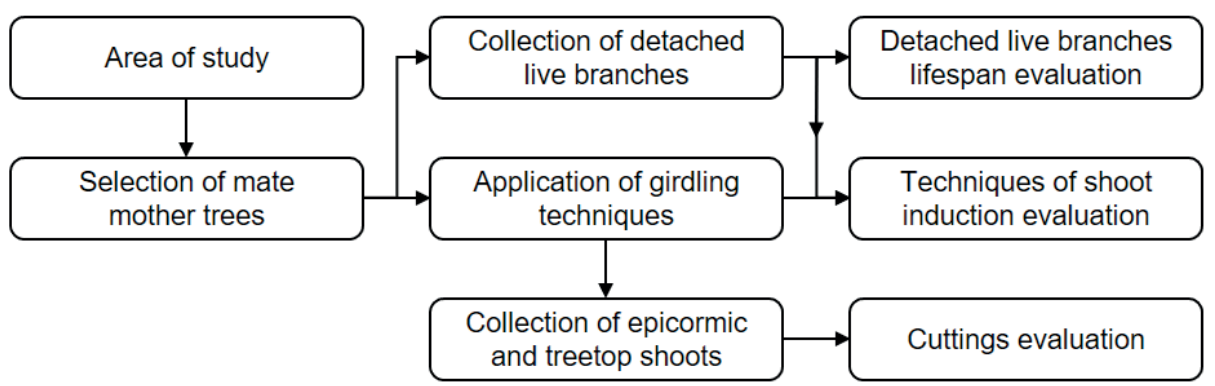

FIGURE 3 A scheme for easy understanding the experiments from the selection of I. paraguariensis mother trees, the application of girdling techniques, to their final evaluation.

The evaluation periods were not significant; the results of the variables are not related to the evaluation periods. The percentage of shooting trees remained between $37.0 \%$ and $51.9 \%$, the average number of shoots formed between 1.4 and 2.9, and the average length of shoots between $1.4 \mathrm{~cm}$ and $3.1 \mathrm{~cm}$.

The technique of detached live branches produced on average almost four times more epicormic shoots (4.7) than the technique of complete girdling (1.2) and more than seven times than the semi-girdling (0.6). Both girdling treatments did not differ statistically (Table I).

TABLE I I. paraguariensis trees and detached live branches with shoots $(\%)$, average number and average length of shoots $(\mathrm{cm})$ according to three rescue techniques in three evaluation periods.

\begin{tabular}{|c|c|c|c|c|c|}
\hline \multicolumn{6}{|c|}{ Trees with shoots (\%) } \\
\hline \multirow{2}{*}{$\begin{array}{l}\text { Induction } \\
\text { technique }\end{array}$} & \multicolumn{3}{|c|}{ Evaluations } & \multirow{2}{*}{ Averages } & \multirow{2}{*}{$\begin{array}{l}\text { Standard } \\
\text { error }\end{array}$} \\
\hline & 210 & $\frac{(\text { days })}{255}$ & 300 & & \\
\hline Girdling (I00\%) & 66.7 & 22.2 & 55.6 & $48.2 \mathrm{a}^{*}$ & \pm 0.1 \\
\hline $\begin{array}{l}\text { Semi-girdling } \\
(50 \%)\end{array}$ & 33.3 & 44.4 & 44.4 & $40.7 \mathrm{a}$ & \pm 0.4 \\
\hline $\begin{array}{c}\text { Detached living } \\
\text { branches }\end{array}$ & 55.6 & 44.4 & 33.3 & $44.4 \mathrm{a}$ & \pm 0.6 \\
\hline \multirow[t]{2}{*}{ Averages } & $51.9 \mathrm{a}$ & $37.0 \mathrm{a}$ & $44.4 \mathrm{a}$ & - & - \\
\hline & verage $n$ & mber o & oots fo & ned & \\
\hline \multirow[t]{2}{*}{$\begin{array}{l}\text { Induction } \\
\text { technique }\end{array}$} & \multicolumn{3}{|c|}{$\begin{array}{c}\text { Evaluations } \\
\text { (days) }\end{array}$} & \multirow[t]{2}{*}{ Averages } & \multirow{2}{*}{$\begin{array}{c}\text { Standard } \\
\text { error }\end{array}$} \\
\hline & 210 & 255 & 300 & & \\
\hline Girdling (I00\%) & 1.2 & I & 1.3 & $1.2 \mathrm{~b}$ & \pm 0.1 \\
\hline $\begin{array}{c}\text { Semi-girdling } \\
(50 \%)\end{array}$ & 0.5 & 0.5 & 0.7 & $0.6 \mathrm{~b}$ & \pm 0.1 \\
\hline $\begin{array}{c}\text { Detached living } \\
\text { branches }\end{array}$ & 7.1 & 4.7 & 2.2 & $4.7 \mathrm{a}$ & \pm 1.0 \\
\hline \multirow[t]{2}{*}{ Averages } & $2.9 \mathrm{a}$ & $2.1 \mathrm{a}$ & $1.4 \mathrm{a}$ & - & - \\
\hline & Average & ength o & hoots & & \\
\hline \multirow[t]{2}{*}{$\begin{array}{l}\text { Induction } \\
\text { technique }\end{array}$} & \multirow{2}{*}{\multicolumn{3}{|c|}{$\begin{array}{c}\text { Evaluations } \\
\text { (days) }\end{array}$}} & \multirow[t]{2}{*}{ Averages } & \multirow[t]{2}{*}{$\begin{array}{c}\text { Standard } \\
\text { error }\end{array}$} \\
\hline & & & & & \\
\hline Girdling (100\%) & 0.8 & 1.3 & 1.9 & $1.3 \mathrm{~b}$ & \pm 0.1 \\
\hline $\begin{array}{l}\text { Semi-girdling } \\
(50 \%)\end{array}$ & 2.9 & 6.7 & 6.4 & $5.3 \mathrm{a}$ & \pm 1.3 \\
\hline $\begin{array}{c}\text { Detached living } \\
\text { branches }\end{array}$ & 0.5 & 0.3 & 0.9 & $0.6 \mathrm{~b}$ & \pm 0.2 \\
\hline Averages & $1.4 \mathrm{a}$ & $2.8 \mathrm{a}$ & $3.1 \mathrm{a}$ & - & - \\
\hline
\end{tabular}

*Averages followed by the same letter do not differ from each other by the non-parametric Kruskal-Wallis test $(P<0.05)$.
I. paraguariensis trees under the condition of semigirdling produced shoots more than four times larger $(5.3 \mathrm{~cm})$ than those under complete girdling $(1.3 \mathrm{~cm})$ and almost nine times than detached live branches $(0.6 \mathrm{~cm})$. The treatments of complete girdling and detached live branches were statistically the same for their shoots average length.

For the treatment of detached live branches, a high production of epicormic shoots was observed. However, these had small length and high number of leaf buds (Figure 4).

Concerning the development of the detached live branches, no statistical difference was detected between the two classes of branch diameter in the shoot formation, however, a significant interaction $(P<0.05)$ was observed between the branch diameter and shooting. The high $R^{2}$ values obtained for both branches larger than $5 \mathrm{~cm}$ (0.87) and less than or equal to $5 \mathrm{~cm}(0.89)$ demonstrate high reliability in applied regression statistics.

The beginning of the shoots formation was verified from the second evaluation (60 days), presenting two shoots on the same branch. From the third evaluation (90 days) there was a significant increase of shooting, from two to more than 60 , distributed in $80.0 \%$ of the branches. This shooting formation lasted until the sixth evaluation ( 180 days), with more than 120 shoots present in up to $90.0 \%$ of the branches (Figure 5).

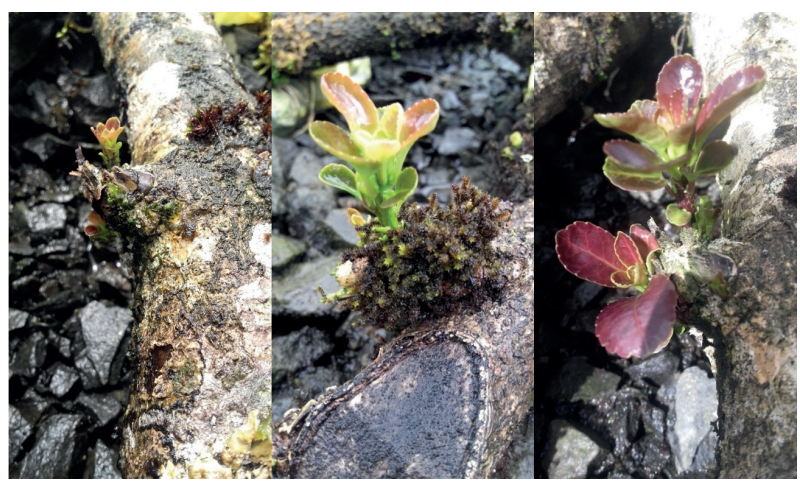

FIGURE 4 Details of the epicormic shoots primordia from I. paraguariensis detached live branches, conditioned in a mini tunnels system at the UDESC Forest Nursery in Lages. 


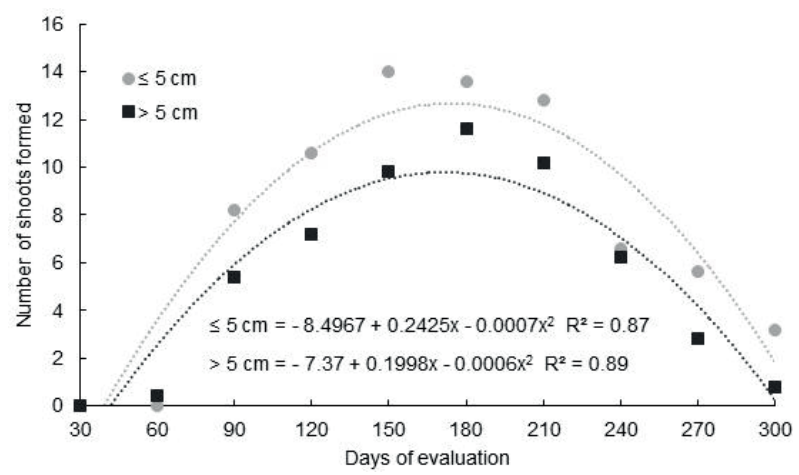

FIGURE 5 Curve of the average number of shoot formation from I. paraguariensis detached live branches according to the evaluation days.

Between the sixth and seventh evaluations (between 180 and 210 days), there was a considerable decrease of shooting on all branches. At the end of the evaluations (300 days), only $30 \%$ of the branches had shoots present (approximately 20 remaining shoots) (Figure 6).

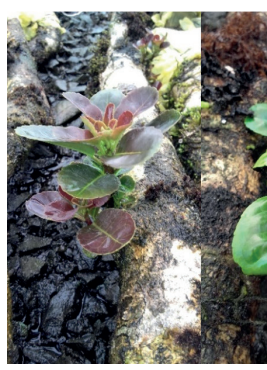

a.

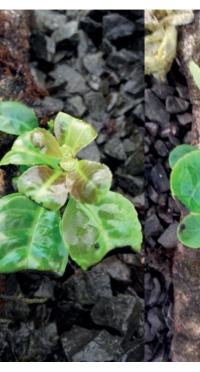

b.

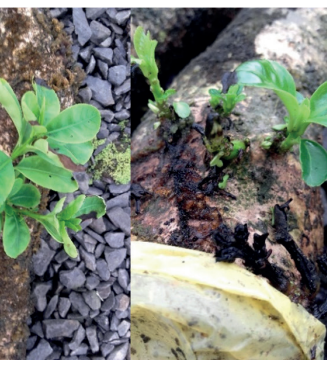

C. d.
FIGURE 6 Epicormic shoots growth from detached live branches according form the start of the evaluations (a - 60 days), during the intermediate evaluations ( $b$ - 150 days, $c$ 240 days) and at the final evaluation ( $d$ - 300 days).

Rooting of cuttings obtained from epicormic and treetop shoots

Comparing the rooting from cuttings of epicormic shoots and treetop, no statistical differences were detected for the variables of survival, rooting, callus formation and average root length. Only observed differences occurred for the average number of roots formed (Table 2).

Although there was no significant difference, there was a greater rooting (approximately 10.0\%) of cuttings made from epicormic shoots (37.3\%) than treetop cuttings $(26.7 \%)$. Cuttings from epicormic shoots presented almost three times more roots (2.3) than the plant material of the treetop $(0.8)$.

\section{DISCUSSION}

\section{Techniques of epicormic shoot induction}

The values obtained according to the selective accuracy (all above $90.0 \%$ ) guarantee a high degree of
TABLE 2 Survival (\%), rooting (\%), callus formation (\%), average root number and average root length $(\mathrm{cm})$ of $I$. paraguariensis cuttings from epicormic and treetop shoots.

\begin{tabular}{ccc}
\hline Treatment & Epicormic shoots & Treetop shoots \\
\hline $\begin{array}{c}\text { Survival } \\
(\%)\end{array}$ & $50.7 \pm 4.1 * \mathrm{a}^{\mathrm{*} *}$ & $56.7 \pm 4.0 \mathrm{a}$ \\
$\begin{array}{c}\text { Rooting } \\
(\%)\end{array}$ & $37.3 \pm 3.9 \mathrm{a}$ & $26.7 \pm 3.6 \mathrm{a}$ \\
$\begin{array}{c}\text { Callus } \\
(\%)\end{array}$ & $20.7 \pm 3.3 \mathrm{a}$ & $28.7 \pm 3.7 \mathrm{a}$ \\
$\begin{array}{c}\text { Number of roots } \\
\text { Root length } \\
(\mathrm{cm})\end{array}$ & $2.3 \pm 0.3 \mathrm{a}$ & $0.8 \pm 0.1 \mathrm{~b}$ \\
\hline
\end{tabular}

*Averages followed by the same letter do not differ by Tukey's average test $(\mathrm{P}<0.05)$; ** Standard error.

confidence in the evaluations and statically analysis carried out (Resende and Duarte, 2007; Navroski et al., 2013).

The mortality of girdled $I$. paraguariensis trees was not detected during and after the experiments. Even though due to the injury caused by the removal of a complete ring from the tree bark, it is not common the case of mortality in this species (Santin et al., 2008). A considerable healing capacity was observed in the girdled area, demonstrating that this technique can be applied without any major damages.

Because it belongs to an area of periodic harvest of green mass, the smallest photosynthesizing area of the trees may have favoured shooting by the girdling techniques. The association between pruning and girdling is able to promote a high percentage of shooting (more than $80.0 \%$ ), with large number of shoots (more than 4 ) and length (more than $16.0 \mathrm{~cm}$ ) in $I$. paraguariensis trees (Santin et al. 2008). However, in the present search, low shooting percentages were obtained and could be caused due to some degree of advanced maturation of the mother trees, or to intrinsic factors of the species adapted to the environment in which it is inserted.

In a similar experiment conducted by Bitencourt et al. (2009), the complete girdling technique in aged I. paraguariensis trees promoted a lower shooting percentage (almost $45.0 \%$ ), but also produced a higher amount of shoots (more than 4 ) and of equal length (I5.0 $\mathrm{cm})$. The percentage of trees with shoots of the present study $(44.5 \%)$ corroborates with the literature, but, the number of shoots is still considerably lower (0.9). I. paraguariensis trees with a high degree of maturation tend to have low vegetative vigor, being a characteristic process of their maturation (Ferreira et al., 2010; Wendling et al., 20I4). However, the trees used in this search are still considered young (between 15 and 20 
years of age), corroborating with the hypothesis of the adaptation of this population to the adverse conditions of local temperature, even in a genetic level.

It is possible that the semi-girdling technique associated with the pruned tree feature exerts a greater capacity of epicormic shooting. This may be associated to the differences caused by hormonal imbalance, allowing a higher average shoot length (Hartmann et al., 20II), once there is still communication between conducting vessels.

Another hypothesis of the low shooting and lower number of shoots formed regarding the girdling techniques would be the environmental conditions, especially the lower temperatures of the study region and to the shade, since it belongs to a native area. However, the genetic characteristics cannot be ruled out regarding the formation of this variable. The high genetic diversity, coming from plants of seminal origin, can influence the promotion of epicormic shoots (Meason et al., 20l6). It is known that this effect can be potentiated by associating stress factors and higher luminosity (Burrows et al., 2010), but it was not detected in this study.

Although the technique of detached live branches is able to produce a large number of shoots, the majority of them have a reduced size (less than $4 \mathrm{~cm}$ ), making their cutting technique quite difficult (Wendling et al., 2013). This was observed in this study, in which many shoots did not reach sufficient size for collection. It is still necessary to develop more specific studies on the epicormic shooting of detached live branches of $I$. paraguariensis (Wendling and Brondani, 20I5) to determine the best procedures to obtain shoots with compatible lengths for the cutting technique.

This same detached live branches lifespan was detected for A. angustifolia and also I. paraguariensis, that with the passage of time there was gradual loss of its shooting capacity (Wendling et al., 2009; Wendling et al., 20I3). This technique also promoted positive results in Eucalyptus cloeziana F. Muell, with shoots developing from 40 days, but without further information on its quantity and length (Almeida et al., 2007).

In a similar experiment with $I$. paraguariensis, there was a low average amount of shoots (5.5) initially produced by detached live branches ( 30 days), decreasing gradually $(4,5)$ in the second evaluation ( 50 days) and third evaluation (average of 2 shoots at 73 days) (Wendling et al., 20I3). In the present search a longer lifespan of the branches was observed, which remained productive until 300 days after the implantation of the experiment. This probably occurred because the branches of this experiment had greater amounts of energy reserves than those of the experiment cited above. In this same search, the detached live branches were placed vertically, which may have enabled a better shooting development, producing shoots of greater length than in the present study. Alternatively, conditions of humidity (always above 90.0\%) and temperature (between $20.4^{\circ} \mathrm{C}$ and $25.7^{\circ} \mathrm{C}$ for the period of greatest shooting, between 90 and 210 days) may have favoured the promotion of the highest number of shoots and their survival for a longer period.

When cutting a branch from the mother tree there is the hormonal imbalance between auxins and cytokines, however, the amount stored in the plant is capable of promoting the production of new shoots (Hartmann et al., 20I I). The collection of live branches for shoot production is a great alternative for species with difficult vegetative propagation, since, besides the lack of cutting down the tree, there is also easy access and greater environmental control present inside the greenhouse (Wendling and Brondani 20I5). It is also necessary to take into account the juvenile characteristics of the branches, their energy reserves and the storage environment, because these factors appear to directly affect their shooting capability.

Rooting of cuttings obtained from epicormic and treetop shoots

The temperature (between $14.0^{\circ} \mathrm{C}$ and $25.7^{\circ} \mathrm{C}$ ) and humidity conditions (always above $90.0 \%$ ) in which the present study was conducted helped to maintain the survival of the I. paraguariensis cuttings at acceptable levels (average of $53.7 \%$ ), as well as in other cutting experiments with the same species (Stuepp et al., 2013). However, the survival of cuttings can be directly related to the age of the mother tree (Stuepp et al., 20I5). The survival of cuttings from aged mother trees that have undergone reinvigoration techniques, such as complete girdling, may be greater than 75.0\%. (Stuepp, 2017b). This difference was not found in the present search, where survival for both materials, whether or not reinvigorated, was statistically equal. This may indicate that, for this variable, there is no need to reinvigorate the plant material in the study area, considering the average age between 15 and 20 years of the mother trees.

Reinvigoration caused by complete girdling may favours the rooting of cuttings from aged mother trees ( 80 years) by more than $55.0 \%$ (Stuepp et al., $2017 b)$. Cuttings of reinvigorated $I$. paraguariensis material significantly increase (up to eight times) their rooting $(65.5 \%)$ compared to the crown (8.5\%) 
(Bitencourt et al., 2009). The reinvigoration did not show to be equally effective in the rooting of cuttings of the present search, not reaching $40.0 \%$. However, the approximate difference of almost $10.0 \%$ of rooting between the materials strengthens the hypothesis that the reinvigoration techniques are effective in the rooting of cuttings, even when carried out in younger plants.

The cutting season and the age of the mother tree can significantly affect its rooting. Cuttings produced in the winter and coming from younger I. paraguariensis trees may have their rooting favoured (more than $75.0 \%$ for 17-year-old plants), while the more aged rooted very little (less than $2.0 \%$ for the same period, of 80 -yearold plants) (Stuepp et al., 2017a). Although with cuttings produced at the same time and, considering as old the treetop material, there was still considerable rooting $(26.7 \%)$. The hypothesis is reinforced that the local population is adapted to the environmental conditions, reflecting in a less general vegetative development, which included in this case also the rooting of cuttings.

The considerable callus formation for both materials $(20.7 \%$ and $28.7 \%)$ of the present search may indicate a future rooting if these cuttings would be kept inside a greenhouse for a longer period of time. I. paraguariensis cuttings from 80 -year-old plants have a high percentage of calluses $(50.0 \%)$, which, if kept longer in greenhouse, have a significant chance of rooting (Stuepp et al., 20l7b). However, the search cited does not give information on the number of rooted cuttings that possessed callus, while the present search brings this information correlated in relation to the total number of cuttings produced. About $45.0 \%$ of the cuttings with calluses rooted, regardless of the degree of juvenility of the material. Callus formation is indicative of high maturation of plant material used for vegetative propagation (Wendling et al., 2014).

The reinvigoration of the cutting material may have been responsible for the greater number of roots and longer length. I. paraguariensis cuttings produced from plant regrowth shoots have a greater number (more than 13) and longer roots (almost $3.0 \mathrm{~cm}$ ) compared to the material produced by the treetop (more than 2.0 and almost $5.0 \mathrm{~cm}$ ) (Bitencourt et al., 2009). However, cuttings reinvigorated by complete girdling may have a lower number of roots (almost 5) and shorter length (less than $1.0 \mathrm{~cm}$ ) (Stuepp et al., $2017 b)$. Proportionally, the reinvigorated cuttings of the present search obtained a greater number of roots (approximately 3 times) than treetop shoots, while the root length was very close $(0.7 \mathrm{~cm}$ and $0.9 \mathrm{~cm})$. The ontogenetic age may be the main responsible for this difference in the number of roots, since epicormic shoots have greater capacity of cellular differentiation than treetop shoots (Almeida et al., 2007).

The differences in rooting, callus formation, number and root length in relation to the cited searchs (Bitencourt et al., 2009; Stuepp et al., 2017a; 2017b) may be related to the degree of maturation of the material used (Ferreira et al., 2010), where the mother trees of the present study could be considered mature due the smaller percentages and number of these variables. I. paraguariensis cuttings have low rooting rates because they are dependent on several factors intrinsic to the species, such as genetic material, physiological quality and age of the mother tree. The main factor associated with the low percentage of rooting is the low juvenility of the propagule used (Wendling and Brondani, 2015). Alternatively, the degree of maturation may not be the main factor hindering rooting, since trees between 15 and 20 years of age were used. The region of material collection has a unique climate, which may have led to an adaptation of the local population. One of the possible adaptations would be the lower vegetative development of this species.

\section{CONCLUSION}

For the production of juvenile epimoric shoots in native I. paraguariensis mother trees, it is recommended the application of the semi-girdling technique to produce shoots of longer length, although they take longer formation time.

It is recommended to use cuttings coming from reinvigorated material inasmuch as they produce a higher average number of roots.

It is not recommended the induction of epicormic shoots for the production of normal cuttings by the technique of detached live branches, due the production of low length shoots despite the high number of leaf buds.

New studies regarding the rescue of plant material from detached live branches need to studied to determine the best technique to elongate its shoots in this species.

\section{REFERENCES}

ALMEIDA, F. D.; XAVIER, A.; DIAS, J. M. M. Propagação vegetativa de árvores selecionadas de Eucalyptus cloeziana F. Muell. por estaquia. Revista Árvore, v. 3 I, n. 3, p. 445453, 2007.

BITENCOURT, J.; ZUFFELLATO-RIBAS, K.C.; WENDLING, I.; KOEHLER, H.S. Enraizamento de estacas de erva-mate (llex paraguariensis A. St.-Hill.) provenientes de brotações revigoradas. Revista Brasileira de Plantas Medicinais., v. II, n. 3, p. 277-28I, 2009a. 
BURROWS, G. E.; HORNBY, S. K.; WATERS, D. A.; BELLAIRS, S. M.; PRIOR, L. D.; BOWMAN, D. M. J. S. A wide diversity of epicormic structures is present in Myrtaceae species in the northern Australian savana biome-implications for adaptation to fire. Australian Journal of Botany, v. 58, n.6, p. 493-507. 2010.

DARTORA, N.; SOUZA, L. M.; PAIVA, S. M.; SCOPARO, C. T.; IACOMINI, M.; GORIN, P. A.; RATTMANN, Y.D.; SASSAKI, G. L. Rhamnogalacturonan from llex paraguariensis: A potential adjuvant in sepsis treatment. Carbohydrate Polymers, v.92, n.2, p.1776-I782, 2013.

FERREIRA, B. G. A.; ZUFFELLATO-RIBAS, K. C.; WENDLING, I.; KOEHLER, H. S.; NOGUEIRA, A. C. Miniestaquia de Sapium glandulatum (Vell.) Pax com o uso de ácido indol butírico e ácido naftaleno acético. Ciência Florestal, v.20, n.I, p.19-31, 2010.

HARTMANN, H. T.; KESTER D. E.; DAVIES JR, F. T.; GENEVE, R. L. Hartmann and Kester's Plant propagation: principles and practices. 8. ed, 2011. $915 \mathrm{p}$.

INSTITUTO BRASILEIRO DE GEOGRAFIA E ESTATÍSTICA, Sistema IBGE de Recuperação Automática - SIDRA. Produção da extração vegetal e da silvicultura de 20 I6. Available at: https://sidra.ibge.gov.br/pesquisa/pevs/ quadros/brasil/2016 Accessed in: 20 June 2018.

MEASON, D. F; KENNEDY, S. G.; DUNGEY, H. S. Two New Zealand-based common garden experiments of the rangewide 'Kuser' clonal collection of Sequoia sempervirens reveal patterns of provenance variation in growth and wood properties. New Forests, v. 47, n. 4, p. 638-65I, 2016.

MEDRADO, J. S. M.; DALZOTO, D. N.; OLIZESKI, A.; MOSELE, S. H. Recuperação de ervais degradados, Embrapa Florestas, 6p, 2002.

NAVROSKI, M. C.; REINIGER, L. R. S.; PEREIRA, M. O.; CURTI, R. A.; PAIM, A. F. Alongamento in vitro de genótipos de Eucalyptus dunnii Maiden. CERNE. v. 19, n. 4, p. 545-550, 2013.

RESENDE, M.D.V. de; DUARTE, J.B. Precisão e controle de qualidade em experimentos de avaliação de cultivares. Pesquisa Agropecuária Tropical, v.37, p. I82-194, 2007.

SANTIN, D.; WENDLING, I.; BENEDETTI, E. L.; BRONDANI, G. E.; REISSMANN, C. B.; MORANDI, D.; ROVEDA, L. F. Poda e anelamento em erva-mate (llex paraguariensis) visando à indução de brotações basais. Pesquisa Florestal Brasileira, n.56, p.97-104, 2008.
STUEPP, C. A.; BITENCOURT, J.; WENDLING, I.; KOEHLER, H. S.; ZUFFELLATO-RIBAS, K. C. Age of stock plants, seasons and iba effect on vegetative propagation of llex paraguariensis. Revista Árvore. v.4I, n.2., p.e4I0204. 20I7a.

STUEPP, C. A.; PEREIRA, G. P.; ZEM, L. M.; PEÑA, M. L. P.; BUENO, P. M. C.; SPADER, V.; ZUFFELLATO-RIBAS, K. C.; ROSA, G. M. Enraizamento de melaleuca: influência da altura de coleta das estacas e aplicação de AIB. Colloquium Agrariae, v.9, p.01-09, 2013.

STUEPP, C. A.; BITENCOURT, J.; WENDLING, I.; KOEHLER, H. S.; ZUFFELLATO-RIBAS, K. C. Indução de brotações epicórmicas por meio de anelamento e decepa em erva-mate. Ciência Florestal, v. 26, n. 3, p. 1009-1022, 2016.

STUEPP, C. A.; BITENCOURT, J.; WENDLING, I.; KOEHLER, H. S.; ZUFFELLATO-RIBAS, K. C. Métodos de resgate e idade cronológicas de plantas-matrizes no enraizamento de brotações epicórmicas de llex paraguariensis. Ciência Florestal, v. 27, n. 4, p. I409-I4I3, 20I7b.

STUEPP, C. A.; BITENCOURT, J.; WENDLING, I.; KOEHLER, H. S.; ZUFFELLATO-RIBAS, K. C. Propagação de erva-mate utilizando brotações de anelamento e decepa em matrizes de duas idades. CERNE, v. 21 , n. 4, p. 519-526. 2015.

WENDLING, I.; BRONDANI, G. E. Produção de mudas de erva-mate. In: WENDLING, I.; SANTIN, D. Propagação e nutrição de erva-mate. EMBRAPA. 21 ed. 2015.

WENDLING, I. Propagação vegetativa de erva-mate (llex paraguariensis Saint Hilaire): estado da arte e tendências futuras. Embrapa Florestas-CNPF, 46 p. (Documentos, n. 91). 2004.

WENDLING, I.; DUTRA, L. F.; HOFFMANN, H. A.; BETTIO, G.; HANSEL, F. Indução de brotações epicórmicas ortotrópicas para a propagação vegetativa de árvores adultas de Araucaria angustifolia. Agronomia Costarricense, v. 33, n. 2, p. 309-319, 2009.

WENDLING, I.; TRUEMAN, S. J.; XAVIER, A. Maturation and related aspects in clonal forestry-part II: reinvigoration, revitalization and juvenility maintenance. New Forests, v. I, p.I-I4, 2014.

WENDLING, I.; BRONDANI, G. E.; BIASSIO, A. de; DUTRA, L. F. Vegetative propagation of adult llex paraguariensis trees through epicormics shoots. Acta Scientiarum, v.35, n.l, p.II7-I25, 2013. 